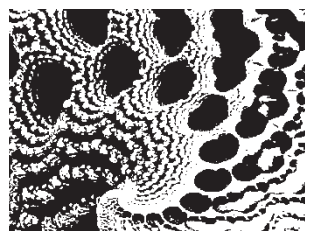

\title{
SURVIVAL GUIDE TO GRAND THEORIZING AND THE CENTRAL DOGMA OF SOCIAL SCIENCE
}

Shing-Chung Jonathan YAM

The Chinese University of Hong Kong, Hong Kong

UDK: 30:001.1

Pregledni rad

Primljeno: 26. 2. 2015.

Grand theorizing and empirical (quantitative or qualitative) research are often separately conducted. In this paper, the separation in question is traced from scholars' differential observance of the yardsticks of the philosophical, scientific and literary/historical methods respectively. The philosophical method relies on deduction and develops into grand theorizing by adding assumptions stemming from life experience, leading to conceptual fluidity. Contrarily, the scientific method relies on experiments, which produce more determinable outcomes as asserted by Popper's (1959) falsificationism. The literary/historical method shares this commitment to determinacy by providing in-depth understanding of spacetime-specific events/meanings. The roles of grand theorizing and empirical research are reviewed: grand theorizing provides categorical schemes, organizes assumptions into perspectives, uncovers hidden assumptions and generates arguments, while empirical research facilitates contextualized comparisons and generates theory. The other side of the story is then presented with the Central Dogma of Social Science, which limits the scope and determinacy of any social understanding with an inverse relationship. The central dogma constrains the possibility of social knowledge and, through institutionalized practice such as the acceptance of journal articles or staff promotion, academic development. For grand theorizing to 'survive', it needs to identify and reembrace its yardstick, which could then lead to confident communication with results generated by other methods.

Keywords: philosophy of social science, epistemology, sociology of knowledge, scope, determinacy

$\triangle \quad$ Shing-Chung Jonathan Yam, Department of Sociology, Rm 431, Sino Building, The Chinese University of Hong Kong, Shatin, Hong Kong. 
DRUŠ. ISTRAŽ. ZAGREB GOD. 25 (2016), BR. 2, STR. $199-218$

YAM, S.-C. J. SURVIVAL GUIDE...

\begin{abstract}
Why, why would Master Chugnis hide his heart? Even I couldn't fully apprehend him, but would have to pick it out from the tales that Granny Story had laboriously gathered. Granny Story chatted with many, many people, used her own ways to synthesize, and everybody's heart was to conveniently crop up in her tales. The tales jumped from person to person to person, people surrounded by people surrounded by people they loved and hated and understood and misconceived, and what I did was simply to stay at his side. Shouldn't I be the one who understood him more?

Master Jonjon, Humanity. Earlier Life (2016)
\end{abstract}

It is to this day that we witness the marginalization of grand theorizing giving rise to a methodologically positivistic (Steinmetz, 2005a, 2005b) sociology. With Skinner (1990), Turner and Boyns' (2001) advocacy and earlier criticisms from Mills (1959) and Gouldner (1970), attempts in clarifying the role of grand theorizing remain sparse, and its relationship to empirical (quantitative or qualitative) research is even more obscure. While grand theories can be characterized as a 'logically-connected system of general propositions' (Abend 2008, p. 177), they attempt to explain a large scope of phenomena with generalized statements. They are thus more ambitious than the theories of empirical research. In line with Wallerstein (1996) and Byrne and Callaghan's (2014) spirit, this paper tells both sides of the story of their relationship (with a synthesis at the end). Specifically, the following two questions are explored:

1) What are the possible relationships between grand theorizing and empirical research?

2) What are the physical conditions that inevitably lead to methodological boundaries (or, simply, why do we need different research methods instead of one unified 'best' method)?

These questions are approached by focusing on the yardsticks behind each method, by delineating its extra-disciplinary origins. Through this exercise, the necessity of methodological pluralism is established and the healthy communication between knowledge generated by each method naturally follows. ${ }^{1}$ The paper first deals with the historical origins of the research methods, clarifying the respective methodological concerns behind them (part one). The answer to the two questions (parts two and three respectively) entails both good and bad news. In part two, the first question is tackled by reviewing the healthy, complementary relationships that the two approaches can have. The bad news comes in part three, where 
DRUŠ. ISTRAŽ. ZAGREB GOD. 25 (2016), BR. 2, STR. $199-218$

YAM, S.-C. J.: SURVIVAL GUIDE... an unavoidable physical limitation to any possible social understanding that humanity can obtain, a result that is referred to as the Central Dogma of Social Science, is discussed. It is further contended that limitations of this kind give rise to methodological pluralism with each method holding on to its yardstick to capture partial truths.

\section{PHILOSOPHICAL, SCIENTIFIC AND LITERARY/HISTORICAL METHODS: METHODOLOGICAL ORIGINS}

Historical studies of methodological debates are not new; Collins (1998) has traced their roots to philosophers of the ancient past, while the postmodernists have been critical of dominant research methods including grand theorizing at some point (Lyotard, 1986) and positivism for most of the time. With methods developing from vastly different disciplinary traditions (Lakatos \& Musgrave, 1970; Papineau, 2007), the encounter of methods in the broad camp of social science generates a need for its disciplines to engage in reflexive studies. The hustling camp of social sciences (sociology, psychology, political science, anthropology, economics) lies at the intersection of humanities (philosophy, linguistics, cultural studies, literature, history) and sciences (physical sciences, biology, ecology, geology, cosmology) and consequently becomes where academic paradigms clash and merge. Legitimacy of methods cycles throughout academic history (Somers, 2005; Steinmetz, 2005c). Methodology evolves over time as trends of academic disciplines. But the question of choice becomes inevitable if they co-exist in the same discipline. The following reviews how these choices have been made as per methodological lineage (entailing implicit yardstick choices) - the adoption of the three socio-scientific methods of grand theorizing, quantitative and qualitative research as developed from the philosophical, scientific and literary/historical methods respectively.

The philosophical method develops deductively, ${ }^{2}$ stemming from intuitive power by a systematic selection of relevant phenomena. Being close to everyday life, it relies on thought processes that are further refined into legitimized streams of thought through academic training in respective philosophical schools. While philosophy is methodologically pluralistic, notably in the division between analytic and continental philosophy, here the term philosophical method is used narrow$l y$, focusing on its distinctive feature only - its reliance on deduction leading to the dominance of logics/rationalism and the absence of methodological empiricism. Grand theorizing develops from this tradition, but with an essential addition the theorist's life experience and imagination - which enriches the set of knowledge on which theories can be constructed. 
DRUŠ. ISTRAŽ. ZAGREB GOD. 25 (2016), BR. 2, STR. 199-218

YAM, S.-C. J.: SURVIVAL GUIDE...
Grand theorizing thus must include some empiricism, although not necessarily methodological, and life experiences and imagination amount to schools of thought (perspectives) with abstracted assumptions and categorical schemes. This addition is necessary because deductive reasoning is impractical for systems as complex as the social.

The problem of this approach is best captured by social psychologists, who have been uncovering fallacies of the common intuition such as probability errors (e.g. Denes-Raj \& Epstein, 1994) and the misconception of others' conceptions (e.g. Savitsky, Epley, \& Gilovich, 2001) - grand theorizing lacks control over the semi-deductive process regarding both starting assumptions/axioms and subsequent assumption-adding procedures. Hidden assumptions can slip in regarding one's biography, imaginative power, and unsystematic sampling of the social world, rendering the process error-prone. There is thus a need for the cultivation of educated guesses to improve accuracy. Besides intra-school training (citing the right masters, which legitimizes), inter-school rivalry can also stimulate intellectual development (Collins, 1998) by clarifying vague concepts and uncovering hidden assumptions and procedural choices.

The scientific method has a shorter history. Here the term is again used narrowly, referring to the use of experiments to generate generalized, replicable findings of causality in the physical science. To achieve this stringent requirement, only extremely simple systems that are anthropically controllable can be studied. Their simplicity allows repeated experiments with a few manageable variables so that everything else can be kept constant. This stringent requirement thus excludes the geological and cosmological science (dealing with historical problems instead, asking the question of what has happened) as well as biological and social science (no two rats and humans are the same and hence results are not perfectly generalizable).

While these requirements make the scientific method highly rigorous, they are also rigid and severely limit the scope of its applicability (Mills, 1959). Quantitative research, as inspired by the scientific method, is therefore confined to the choice of a topic limited by the possibility of acquiring relevant data that could suggest causality by incorporating and avoiding as many confounding and colliding variables as possible (see also: Morgan \& Winship, 2015; Outhwaite \& Turner, 2007; Shahar \& Shahar, 2012). The social sphere is an open system, which defies experimental designs, not to mention historical events that happen only once. Quantitative research can therefore only focus on topics that have little interaction with external institutions - a rare scenario. There is thus an ampliation of re- 
DRUŠ. ISTRAŽ. ZAGREB GOD. 25 (2016), BR. 2, STR. 199-218

YAM, S.-C. J.: SURVIVAL GUIDE... search methods to capture partial truths in non-physical sciences, namely, astronomical observations, excavations, quasi-experiments, statistical and correlation studies and so on. Research rigor is impaired in many areas: the process can be unrepeatable, the ceteris paribus condition not satisfied, exact data not available or the data insufficient to eliminate alternative causal mechanisms. Quantitative research's mimicry is therefore partial, a theme well sung by the critics of positivism in social science.

Finally, besides philosophy and science, there is yet another source of methodological inspiration for social science - literature and history - which gives rise to qualitative research. The literary/historical method is similar to the scientific method in that it relies heavily on induction and has an acute focus. However, the scientific method produces generalized results with a reduced variable set, while the literary/historical method does quite the opposite - it produces spacetime-specific results while embracing the full set of variables/phenomena (holism). ${ }^{3}$ Qualitative research such as archival research, interpretive approaches and ethnography thus explores the depths of particular manifestations of our human history, with each research enriching our knowledge of what has happened (descriptive) or been expressed (hermeneutical).

Assuming the reader is familiar with the sociology and philosophy of science, and in particular, the theories of Hume, Peirce, Popper, Kuhn and Lakatos, we will now explore the relationships between these three research methods with focus on their functional roles in the academic research cycle.

\section{HOW GRAND THEORIZING MIGHT WORK WITH EMPIRICAL RESEARCH}

Research methods undergo their own institutionalization, leading to islands of academic activities - they are taught in separate courses ('Sociological theory' vs. 'Statistical analysis' and 'Qualitative methods') and appear in specialized journals. Nonetheless, empirical research requires theory to advance its research cycle in order to generate generalized knowledge.4 There are thus a number of intellectual functions that grand theorizing and empirical research can provide to each other.

First, grand theories can provide classification schemes through 'typification' and anonymization (Berger \& Luckmann, 1967, pp. 30-38) (e.g. Parsons' [1937, 1951] 'action' and 'AGIL' schemes). Classification schemes reduce complexity by grouping similar phenomena into a single description. This reduces the number of elements to be described, enhancing comprehensibility. The price to pay is a reduction in 'descriptive accuracy' (Heckathorn, 1984) due to a loss of information of ingroup heterogeneity. Classification schemes generate con- 
DRUŠ. ISTRAŽ. ZAGREB GOD. 25 (2016), BR. 2, STR. 199-218

YAM, S.-C. J.: SURVIVAL GUIDE... cepts, which 'criss-cross' to form languages (Wittgenstein, 1953) for scholars to converse in - the basic function of grand theories before other functions can take shape.

Second, grand theories can act as perspectives by declaring relationships among concepts from their categorical scheme. Now such theorizing can entail many activities, noted by Byrne and Callaghan (2014, p. 154) as 'description', 'trending' and 'establishment of cause(s)'. The power of perspective is a reorientation of focus, hence allowing us to leap from an overly local intuition to somewhere fresh. Perspectives thus suggest new worldviews but fall short of giving predictions, the latter of which involves the empirical testing between intuitive yet contradictory understandings.

Here, elegance plays a key role in a theory's success. Theories should explain many phenomena while remaining simple: Bourdieu's (1984) field-capital-habitus theory describes the development of the habitus within logics of fields, while Luhmann's (1995) autopoietic system divides systems within systems no matter how many linguistic maintenance mechanisms he tried to pack into them. They both generate a (possibly complicated) worldview with a simple classification scheme. Contrarily, Turner's (2010a, 2010b, 2012) macro-meso-micro model for society relies on arbitrarily long lists of variables in his three-level society. Non-exhaustive lists undermine both explanatory power (failing to capture the full scope of sociality) and elegance (leading to an explosion of complexity in terms of the number of categories and relationships), and adding levels creates categorization problems - the correct levelling of social phenomena. Turner $(2010 a, 2010 b, 2012)$ has thus ventured into the taboo region of theory-research divide, having moved towards middle-range theory through working with operationalized concepts.

Third, with the perspective function firmly established, grand theories can uncover hidden assumptions in other theories or research results especially when they become overly-institutionalized schools of thought. In the case of the philosophical method, this would typically involve reactions to existing perspectives. The discovery of hidden assumptions can lead to a multitude of consequences: the target can remain with the assumption deemed irrelevant, or it can be modified, rejected or replaced as in the maintenance of Kuhn's universally accepted paradigm / Lakatos' hardcore, a change in Lakatos' protective belt, Popper's falsification, or Kuhn's paradigm shift. Besides these academic developments, extra-academic factors also come into play: relative prestige between individuals and schools, technological limitations and societal / political trends - themes that have been studied extensively by Collins (1998). 
DRUŠ. ISTRAŽ. ZAGREB GOD. 25 (2016), BR. 2 STR. 199-218

YAM, S.-C. J.: SURVIVAL GUIDE...
Finally, as grand theories maturate and develop they can also generate theoretical arguments / middle-range theories / empirical theories. This completes the research cycle of the scientific method. By moving closer to research (e.g. Perz, 2007), these middle-grounds can expand the contexts, setup and interpretation of research - or as discussed by Aakvaag (2013, p. 207) - as a 'sensitizing device' for research design. Empirical theories can generate testable hypotheses, thus breaking free from theorizing's deduction / semi-deduction. This function is hard to realize without legitimized channels of inter-methodological communication, leaving an academic vacuum between theorizing and research (we shall see why this is the case when we come to the effect of academic yardsticks to methodological development).

Grand theorizing can also benefit from empirical research. Empirical research provides contextualized comparisons among theories, enhancing the accuracy of theoretical claims through better 'articulation' as well as empirical testing (Aakvaag, 2013). Besides induction, this can also be done through simulation algorithms, which create their axiom-based 'world' generating a massive number of theories possibly followed by their testing - i.e., Hayles' (1999, pp. 12-13) 'Platonic forehand'. Through this, research can generate theories, enriching our imagination beyond lifetime experience. This is not the usual way theorists theorize - they descend from philosophers, who talk to established masters dead or alive rather than methodologically-generated data. But advocacies for this rarer form of theorizing have been emerging recently, including pedagogical discussions (e.g., Swedberg, 2016).

Earlier attempts have always been with us though. Peirce (1931-1958) spent a lifetime developing 'abduction'/retroduction', enriching (read: changing) its definition to the extent of incorporating both deduction and induction into it (Chiasson, 2001). In one of its more refined definitions, retroduction concerns finding an explanation so that a surprising observation 'would be a matter of course' (Peirce, 1934, pp. V, 117). This serves as a starting point for the procedural discussion of retroduction as theorizing (Carleheden, 2014, p. 433: retroduction as the investigation of 'the conditions of the possibility of something', after Kant; Swedberg, 2012). But at this point the deductive rigor of philosophy/logic becomes unhelpful, the culprit being the search phase - for this involves the infinite possibilities of aesthetics, creativity and (experientially and culturally-defined) common sense, which are hard to tame no matter how hard Peirce tried. Partial specifications are, of course, possible (for a procedural discussion of retroduction, see Chiasson, 2001), and in fact much research is yet to be done in this area. 
DRUŠ. ISTRAŽ. ZAGREB GOD. 25 (2016), BR. 2, STR. 199-218

YAM, S.-C. J. SURVIVAL GUIDE..
Research activities along this direction are often stigmatized as ex post facto explanations in a normative climate of empirical tests, rendering these activities illegitimate. But this can lead to theories being under-utilized (Turner, 2002). This is, however, understandable, for the complexity of induction makes theorizing hard to evaluate - multiple and a possibly infinite number of explanations can arise (Barnes, 1990). But the decline of theorizing is nonetheless a weak point in our academic endeavour, and there are pragmatic reasons too we have to go through research cycles to figure out how much confidence we should place on choices. This makes the needs for a favourable climate for theorizing all the more urgent.

At this point it should be clarified that this discussion so far is about idealized methods, not actual practice. Despite the preceding focus on the history of methods, our aim is to investigate methodological yardsticks in view of our physical constraints rather than an investigation on what scholars have been doing. In a similar vein, Popper's $(1959,1963,2008)$ falsificationism and Kuhn's (1970) paradigm shift can be placed side by side without contradiction - i.e., falsification is a crucial step in an idealized scientific method but is then subject to practicalities of paradigmatic thinking. There are ways to formulate these practicalities, e.g., with the additional step of a Bayesian evaluation (or worse, qualitatively in the form of educated intuition) of alternative hypotheses of the research against theories under the dominant paradigm: that either the theory is right and the experiment is faulty, or the theory is wrong and the experiment is sound.

This additional step is where tacit knowledge (Polanyi, 1958) comes in because anything can go wrong in the actual world. Besides faulty research, extra-academic concerns can also slip in: political pressure, funding, research significance, researchers' prestige, confidence in the orthodox theory, time, effort. These contexts bound possible relationships between method and knowledge, a central theme in the sociology of science and knowledge.

\section{THE CENTRAL DOGMA OF SOCIAL SCIENCE: SCOPE, DETERMINACY, SIMPLICITY, ELEGANCE, PREDICTABILITY}

Up till now our story is an optimistic one. Grand theories and empirical results can be communicating. Here comes the other side - physical factors that, while prompting these communications, limit the kinds of knowledge that anyone can generate. Two such factors are specifically discussed: information loss in categorization / conceptualization, and complexity due to an infinite number of variables/cases.

Categorical schemes can enhance computational capacity by regrouping, but the results of regrouping would still be subject to three limitations: limits of information entropy (Shan- 
DRUŠ. ISTRAŽ. ZAGREB GOD. 25 (2016), BR. 2 STR. 199-218

YAM, S.-C. J.: SURVIVAL GUIDE... non, 1948), linguistic limits, and 'descriptive accuracy' (Heckathorn, 1984) due to in-group heterogeneity. The first limitation stems from the computational capacity of the human brain. Social understandings are thus subject to both procedural (one logical step at a time) and data limitations (Miller, 1956; Baddeley, 1994). The second problem is most prominent in unquantifiable concepts that defy quantitative research methods. From Baldamus' (1972, 1976, p. 40) 'double fitting' we know that both concepts and data are fuzzy; theory and research are thus prone to linguistic mismatch. The third problem happens as an overhead to categorization, because categories take up space and have to be further managed and indexed. There cannot be too many categories (which defies their original purpose), but too few would over-simplify - this typically happens in mathematical or simulation models, where their application in the open world becomes questionable.

Here are some common categorical schemes: micro-macro, system-environment, Parsons' social system, field-habitus-capital, powerful-powerless, structure-agent, core-peripheral, core-semi-peripheral-peripheral, and market-externality. Irrespective of the choice of schemes, the resultant information loss would lead to Mills' (1959, pp. 123-124) dilemma between grand theory and abstract empiricism - they both try to escape from common-sense empiricism so that in the former 'the idea is too large for the content' while for the latter 'the content swallows the idea'. A similar problem exists at the high-determinacy side when Popper (1963) touched upon the dilemma between probability and content in science.

Complex theories sound ad hoc as a result, and a theory that spans libraries is impractical. This requirement is also known as elegance - fulfilling an analytical goal while staying simple. An elegant theory is bound to lack predictability outside its scope, but drawing its boundary of application could be equally difficult because boundary-setting is also a descriptive endeavour, hence subject to the same limitation. Consider the micro-macro divide, a problem that has haunted sociologists for decades. Recall that Turner's (2002, 2010a, 2010b, 2012) bridging attempt was to add a meso level and attribute variables to each level. While meso concepts can enhance descriptive accuracy, this expanded categorical scheme has resulted in more bridging problems (from one to two, with the hope that they are easier to tame) and created further difficulties in the consistent attribution of concepts to categories. The progress from two to three or four or more levels thus comes with the price of complexity.

Because grand theories have a scope that cuts across multiple social phenomena, they can be interpreted with their scope contracted or expanded. Once operationalized explicit- 
DRUŠ. ISTRAŽ. ZAGREB GOD. 25 (2016), BR. 2, STR. $199-218$

YAM, S.-C. J. SURVIVAL GUIDE... ly, they become tautologically true in some instances of scope contraction and false through repeated scope expansion. ${ }^{5}$ Thus, they have indefinite interpretations between two extremes. The expanded interpretation requires them to be true under every context, which is impossible because all theories necessarily have a central focus for them to be describable. The contracted interpretation suggests that they are true under the right conditions without stating those conditions (boundary-setting is difficult), hence placing the validity burden on the users. For example, while the understanding of the market system can be facilitated by investigating its internal logic, it is also apparent that this approach is limited - 'externalities' perpetually complicate the picture: power struggles between the dominant party and other coalitions, cultural conceptions of money and trade, legal texts and their means of enforcement, unquantifiable human nature regarding possessions, relationships, social status, individual differences in preference and so on. Without the hidden assumption function of grand theories, quantitative research can run into the studying of mathematical models, or worse, an orthodox model, without clear indication as to how these models can be applied to social reality.

Complexity problems arise irrespective of where we start our journey of scope expansion. Consider ascending from the micro level slightly, from an individual to a dyad. The individual level consists of an input-output agent, which entails inborn and nurtured prerequisites (contributing to preference, thinking pattern and behavior) with respect to its natural environment. With the research interest of social science, the individual is separately conceptualized, described with more accuracy. But by moving onto dyadic relationships, many more external possibilities suddenly come into play - the agents' meaning-making of each other's meaning-making of each other and so on as recursions of mutually-facing looking glasses (extending Cooley, 1998) ad infinitum - so that an ordered list of words, gestures, positions and thoughts down to their minute detail is required for accurate analyses. What was once more predictable now becomes much more difficult to describe or analyze because of an emergent of attributes.

Complexity also surges if we start from the macro. Here we have statistics of a population, giving a general idea of the latter while throwing away the rest of its heterogeneity. Travelling down, in-category individual differences begin to emerge, and increasingly more statistics are needed to describe the situation. Social science thus faces this dilemma between scope and determinacy due to the complexity of its subject matter - on the one hand, grand theorizing has lost its deductive rigor and hence determinacy through the addition of 
DRUŠ. ISTRAŽ. ZAGREB GOD. 25 (2016), BR. 2 STR. 199-218

YAM, S.-C. J.: SURVIVAL GUIDE... hidden assumptions and scope expansion. On the other, with limited variables, quantitative methods can only investigate a limited number of variables, reducing their predictability, while qualitative methods are also restricted in scope but in another way - the results that they generate are locked in particular spacetime contexts: a community, a piece of literature, etc. Research results under these paradigms have a low scope (omitting many variables or cases) with the benefit of determinacy within an artificial boundary.

Predictability requires both scope and determinacy, but adding determinacy requires reducing the scope (focus limited to some variables/cases) to remain simple enough for rigorous investigations. This gives us a relationship between scope, determinacy and simplicity, with simplicity setting a bound to both. This also calls for the impossibility of satisfying all academic requirements (Longino, 1990), which happens in other disciplines of complexity as well such as fluid dynamics and artificial intelligence (Zhou et al., 2010).

The complexity of the social, while theoretically it can be boiled down to a (hopefully finite) set of physical laws (thus reducing social science to physics), cannot be carried out anthropically. This is because this operation requires not only these laws but also a huge information set: the initial condition such as a snapshot of every particle and energy distribution (position, momentum, mass, charge and so on) in the system that we are interested in. ${ }^{6}$ It is from this snapshot that we can deduce, using the known physical laws, what we want to know by simulating a model that assembles humans and their environment from bits (yielding another problem: computational capacity). Such a snapshot is technologically impossible, both because a technology of such precise and extensive measurement does not exist and because of the reflexivity problem: the problem of measuring oneself. This is also why empirical studies require induction besides deduction: a purely deductive method, which is completely determinable, requires such an impossible snapshot as a starting point. Finally, physical laws are the 'axioms' of our physical world and are hence independent from logical axioms. A reductionist approach based on physical laws, given our limited descriptive capacity of the universe, can thus only capture an insignificant scope of social reality.

These methodological limitations lead us to the following metasocio-science result:

\section{Central Dogma of Social Science}

Scope and determinacy of any social understanding are limited by an inverse relationship, where it attains maximum manageable complexity. 
DRUŠ. ISTRAŽ. ZAGREB GOD. 25 (2016), BR. 2, STR. 199-218

YAM, S.-C. J. SURVIVAL GUIDE...

\section{DISCUSSION}

The central dogma limits the form of any social understanding (grand theory or empirical research result) anthropically-epistemically. The last two adverbs are stressed, because the central dogma has little direct ontological implication instead, it applies to how humans and the like as physical beings are to acquire knowledge from the world that they are part of. Moreover, this limitation is a 'central dogma' in the sense that it is thrust upon everyone whether we like it or not - despite Latour's $(2005 a, 2005 b)$ attempts in bridging the unbridgeable, the map is still far from being a territory.

We witness this anthropic limitation whenever scholars try to add back complexity to the knowledge simplified from our world of complexity. James (1912) and Latour's (2005b, p. 24) 'radical empiricism' / 'second empiricism' attempted to conceptualize and hence acquire experience and reductionistic (scientific) knowledge as one, Fuhse (2009) added back 'meaning structure' to network theory, and neofunctionalists (e.g. Alexander, 1998) deserve their mention by pushing the envelope of just how complex systems can co-behave. But soon, these efforts build up in complexity and bump into the central dogma - and bam! - further progress ceases in the originally envisioned direction. The only way out, besides staying where you are, would be to move sideways; this would be a timely topic - the rise of interdisciplinarity and mixed methods, which has to be handled by another paper.

The dogma's limit to manageability can be broken down into two components: computability and measurability. Constraints on computability limit the variety of conceivable realities reachable by deduction while constraints on measurability limit the scope of information obtainable as raw materials of deduction. Both constraints have physical and biological causes from 'economy of research' (Peirce, 1879) to research complexity (Diez, 2011, p. 109). Consequently, the yardsticks of scope, determinacy or any of their combinations create academically-legitimate islands separated by vacuums of taboo. Separate institutionalization of research methods leads to differentiation of yardsticks (Bulmer, 1984; Hitt, Gimeno, \& Hoskisson, 1998; Yanow \& Schwartz-Shea, 2006), and dialogues between methodological schools can be futile, even though they could be studying the same phenomena, unless these yardsticks are made explicit and communicable. An example would be a time when grand theories and quantitative research have developed to a point where they operate at different levels of analysis, failing to communicate with each other (Coleman, 1998).

Grand theorizing, quantitative research, qualitative research, the scientific, philosophical and literary/historical methods have their own combination of yardsticks and comfort zone. Re- 
DRUŠ. ISTRAŽ. ZAGREB GOD. 25 (2016), BR. 2 STR. 199-218

YAM, S.-C. J.: SURVIVAL GUIDE... search practices emerge out of these idealized methods through differential observance of these yardsticks. Methods can also have built-in metaheuristics with observance to their yardsticks. This allows researchers to search intelligently in an otherwise prohibitively large solution space: the use of deduction whenever possible, the tendency to criticize giants only, and the accumulation of experience (intelligent search with tacit knowledge / intuition) to choose research methods and questions. An exhaustive search for explanations to our universe is inefficient - there are infinite possibilities in our solution space, while research and theorizing can benefit from sensible topic and research design. There is thus this necessity of intelligent search as part of our research practice, something that Popper's anti-inductivism failed to take account of. In fact, probability, fuzzy logic, or other more obscure concepts (Peirce / Popper / Margolis: verisimilitude; frequentist: confidence; Popper: degree of corroboration) would not eliminate this necessity, but they can contribute to the overall process by helping with the evaluation of alternatives. There is also a practical side to this, because we have to use academic knowledge at some point and our empirical research has to sensibly base on something in order to continue its development.

The philosophical method aims for perfect determinacy (logical operations only) while the scientific method ventures a step into empirical, physical scope. Going further into social scope, quantitative and qualitative research aim for determinacy at the expense of scope. The expansion of grand theory into institutions covering ever-more social phenomena develops towards scope at the expense of determinacy. These methods thus have three academic vacuums in-between: theory-research divide, social-physical divide and inductive-deductive divide. The theory-research divide arises due to the conflicting yardsticks of determinacy and scope in the context of social/human science. The social-physical divide arises out of the conflict between scientific determinacy and our interest in the social world (social scope). The inductive-deductive divide arises due to difficulties in the mathematical formulation of our physical world. Their positions are shown in Figure 1.

The above discussion, however, does not predict whether grand theorizing and empirical research must or should develop towards scope, simplicity or determinacy - this would be a confusion of idealized methods with research practice. For example, academic disciplines can embrace complexity and scope by incorporating ever-more perspectives: physical, biological, psychological, political, economic, cultural and sociological. But the actual direction of academic development depends on the way how disciplines evaluate between 
DRUŠ. ISTRAŽ. ZAGREB GOD. 25 (2016), BR. 2, STR. 199-218

YAM, S.-C. J.: SURVIVAL GUIDE.. yardsticks. It is thus a process of how academic prestige institutionalizes (e.g., Mouton \& Marais, 1988). But then, institutions become traditions, and yardstick choice persists. Research output within each academic coalition legitimizes and gains legitimacy from its observance of yardstick at the same time. Cultures surrounding yardsticks thus place further constraints on research activities beyond the central dogma; alternative developmental directions become taboo.

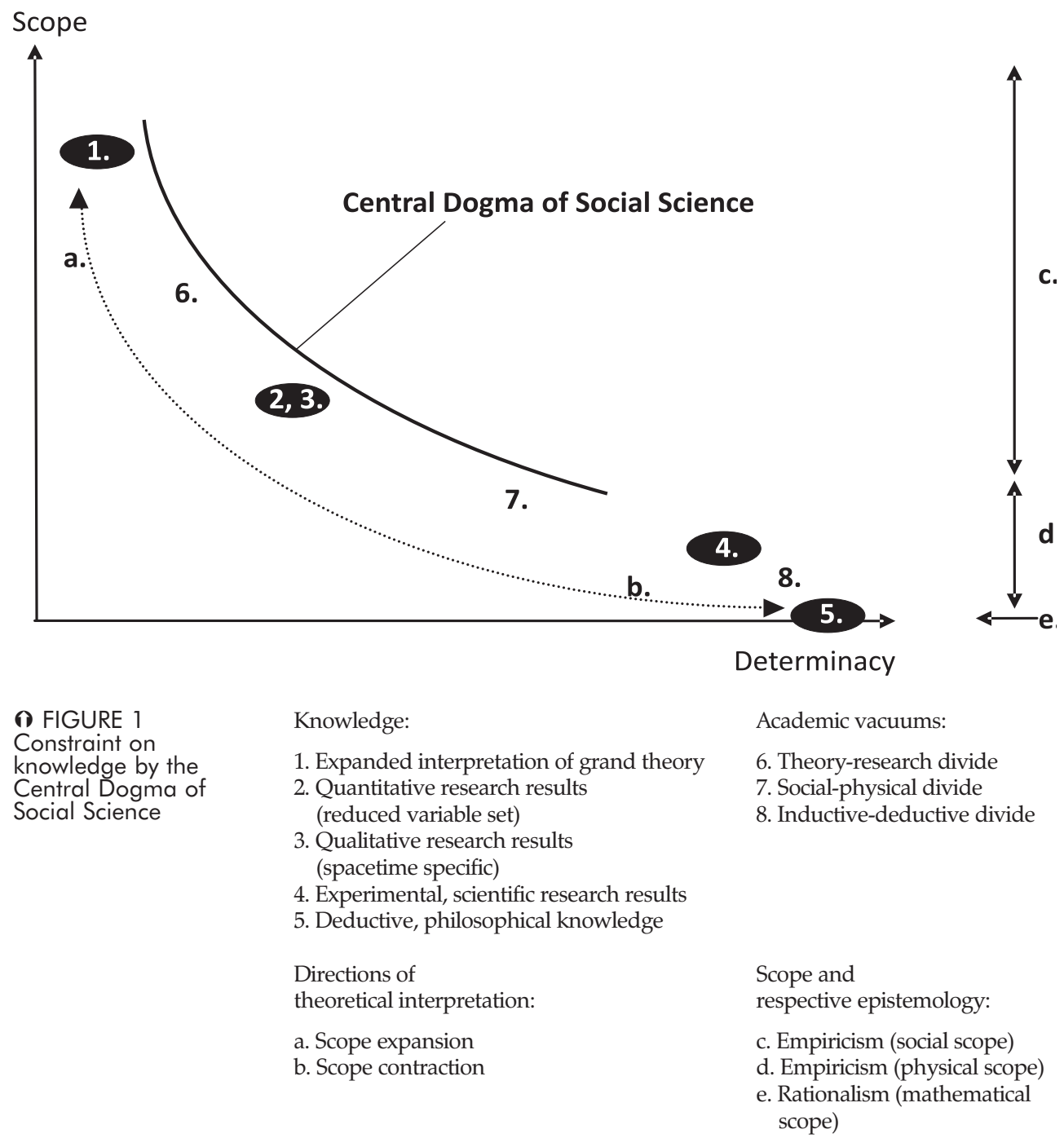

To survive in a competitive setting is to acknowledge functionality. What are we to admire social science for, if not for methodological diversity? In this paper the existence, necessity and origins of methodological yardsticks are thus clarified, following social science's increasing concern for reflexivity 
DRUŠ. ISTRAŽ. ZAGREB GOD. 25 (2016), BR. 2, STR. 199-218

YAM, S.-C. J.: SURVIVAL GUIDE... (e.g. sociology of knowledge). The necessity part is illustrated with the Central Dogma of Social Science, which constrains what we can know and to what accuracy. Social science lacks the traditional credentials of philosophy, history and literature as well as the prestige of science (Lepenies, 1988) and hence suffers from an ongoing crisis of self-identity. The rise of the commercial sector and transformation of education into workforce training has led to the falling social importance of all of the above. But it is social science that gives us the possibility of understanding ourselves; knowing our limitations can thus be the first step to the appreciation of its diversity.

\section{NOTES}

\section{REFERENCES}

1 There are other ways to achieve this second point. For example, Aakvaag (2013) connected theory and research through middleground 'social mechanisms'.

2 Both the rationalist and empiricist schools in philosophy are developed deductively. In particular, what the empiricist school claims should not be confused with the method used to reach such claims. This methodological background does limit how radical the empiricist doctrine can be interpreted - contradictions happen in the case of radicalism.

3 The current trend of institutionalization and fragmentation of qualitative methods, however, has weakened this insistence on holistic scope. For example, see Atkinson (2005).

4 This interest in research cycle and generalized knowledge is traditionally confined to quantitative research. However, with more diverse qualitative methods such as ethnology, it is perfectly possible for qualitative disciplines to engage in theorizing.

${ }^{5}$ If, unfortunately, they are conceptually too specific and are false in any instance of scope contraction, they fail to be theories at all. This gives incentives to theorists to follow a road of vagueness.

${ }^{6}$ Assuming a naturalistic and deterministic universe; further complications arise otherwise as in the case of the Copenhagen interpretation of quantum mechanics.

Aakvaag, G. C. (2013). Social mechanisms and grand theories of Modernity - worlds apart? Acta Sociologica, 56(3), 199-212. doi:10. $1177 / 0001699312468804$

Alexander, J. C. (1998). Neofunctionalism and after. Oxford: Blackwell Publishers.

Abend, G. (2008). The meaning of 'theory'. Sociological Theory, 26(2), 173-199. doi:10.1111/j.1467-9558.2008.00324.x

Atkinson, P. (2005). Qualitative research - unity and diversity. Forum: Qualitative Social Research, 6(3). http://www.qualitative-research.net/ index.php/fqs/article/download/4/10

Baddeley, A. (1994). The magical number seven: Still magic after all these years? Psychological Review, 101(2), 353-356. doi:10.1037/0033295X.101.2.353 
DRUŠ. ISTRAŽ. ZAGREB GOD. 25 (2016), BR. 2, STR. 199-218

YAM, S.-C. J.: SURVIVAL GUIDE...
Baldamus, W. (1972). The role of discoveries in social science. In T. Shanin (Ed.), The rules of the game (pp. 276-302). London: Tavistock Publications.

Baldamus, W. (1976). The structure of sociological inference. New York: Barnes \& Noble.

Barnes, B. [1985] (1990). Thomas Khun. In Q. Skinner (Ed.), The return of grand theory in the human sciences (pp. 83-100). Cambridge: Cambridge University Press. Canto edition.

Berger, P. L., \& Luckmann, T. (1967). The social construction of reality: A treatise in the sociology of knowledge. New York: Anchor.

Bourdieu, P. (1984). Distinction: A social critique of the judgement of taste. London: Routledge.

Bulmer, M. (1984). The Chicago school of sociology. Chicago: The University of Chicago Press.

Byrne, D., \& Callaghan, G. (2014). Complexity theory and the social sciences: The state of the art. Oxon: Routledge.

Carleheden, M. (2014). On theorizing: C.S. Peirce and contemporary social science. In A. Laitinen et al. (Eds.), Inwardness and orientation festschrift in honor of Jussi Kotkavirta (428-459). Jyvaskyla: University of Jyvaskyla.

Chiasson, P. (2001). Abduction as an aspect of retroduction. In M. Bergman \& J. Queiroz (Eds.), The Commens Encyclopedia: The Digital Encyclopedia of Peirce Studies, new edition. http://www.commens.org/ encyclopedia/article/chiasson-phyllis-abduction-aspect-retroduction

Coleman, J. (1998). Foundations of social theory. Cambridge, Massachusetts: Belknap Press of Harvard University Press.

Collins, R. (1998). The sociology of philosophies: A global theory of intellectual change. Cambridge, Massachusetts: Belknap Press of Harvard University Press.

Cooley, C. H. (1998). On self and social organization. Chicago: University of Chicago Press.

Denes-Raj, V., \& Epstein, S. (1994). Conflict between intuitive and rational processing: When people behave against their better judgment. Journal of Personality and Social Psychology, 66(5), 819-829. doi:10.1037/0022-3514.66.5.819

Diez, J. A. (2011). On Popper's strong inductivism (or strongly inconsistent anti-inductivism). Studies in History and Philosophy of Science, 42(1), 105-116. doi:10.1016/j.shpsa.2010.11.023

Fuhse, J. A. (2009). The meaning structure of social networks. Sociological Theory, 27(1), 51-73. doi:10.1111/j.1467-9558.2009.00338.x

Gouldner, A. W. (1970). The coming crisis of western sociology. New York: Basic Books.

Hayles, K. (1999). How we became posthuman: Virtual bodies in cybernetics, literature and informatics. Chicago, IL: University of Chicago Press. doi:10.7208/chicago/9780226321394.001.0001

Heckathorn, D. D. (1984). Mathematical theory construction in sociology: Analytic power, scope, and descriptive accuracy as trade-offs. The Journal of Mathematical Sociology, 10(3-4), 295-323. doi:10.1080/ 0022250X.1984.9989973 
DRUŠ. ISTRAŽ. ZAGREB GOD. 25 (2016), BR. 2 STR. 199-218

YAM, S.-C. J.: SURVIVAL GUIDE...
Hitt, M. A., Gimeno, J., \& Hoskisson, R. E. (1998). Current and future research methods in strategic management. Organizational Research Methods, 1(1), 6-44. doi:10.1177/109442819800100103

James, W. (1912). Essays in radical empiricism. New York: Longmans.

King, G., Keohane, R. O., \& Verba, S. (1996). Designing social inquiry: Scientific inference in qualitative research. Princeton: Princeton University Press.

Kuhn, T. (1970). The structure of scientific revolutions. Chicago: University of Chicago Press.

Lakatos, I., \& Musgrave, A. (1970). Criticism and the growth of knowledge. Cambridge: Cambridge University Press. doi:10.1017/cbo97811 39171434

Latour, B. (2005a). Reassembling the social: An introduction to actor-network-theory. Oxford: Oxford University Press.

Latour, B. (2005b). What is the style of matters of concern? Spinoza Lectures. Department of Philosophy, University of Amsterdam.

Lepenies, W. (1988). Between literature and science: The rise of sociology. Cambridge: Cambridge University Press.

Longino, H. E. (1990). Science as social knowledge: Values and objectivity in scientific inquiry. Princeton: Princeton University Press.

Luhmann, N. (1995). Social systems. Redwood City: Stanford University Press.

Lyotard, J. F. (1986). The postmodern condition: A report on knowledge. Oxford: Manchester University Press.

Miller, G. A. (1956). The magical number seven, plus or minus two: Some limits on our capacity for processing information. Psychological Review, 63(2), 81-97. doi:10.1037/h0043158

Mills, C. W. (1959). The sociological imagination. New York: Oxford University Press. doi:10.2307/1891592

Morgan, S. L., \& Winship, C. (2015). Counterfactuals and causal inference: Methods and principles for social research. 2nd edition. Cambridge: Cambridge University Press.

Mouton, J., \& Marais, H. C. [1988] (1990). Basic concepts: The methodology of the social sciences. Cape Town: HSRC Publishers.

Outhwaite, W., \& Turner, S. P. (2007). The SAGE handbook of social science methodology. London: SAGE Publications. doi:10.4135/97818486 07958

Papineau, D. (2007). Philosophy of science. In N. Bunnin \& E. P. Tsui-James (Eds.), The Blackwell companion to philosophy (Second Edition) (pp. 286-316). Oxford: Blackwell Publishing. doi:10.1002/9780470996362 Parsons, T. (1937). The structure of social action: A study in social theory with special reference to a group of recent European writers. New York: The Free Press.

Parsons, T. (1951). The social system. London: Routledge.

Peirce, C. S. (1879) [1967]. Note on the theory of the economy of research. Operations Research, 15(4), 643-648. doi:10.1287/opre.15.4.643 
DRUŠ. ISTRAŽ. ZAGREB GOD. 25 (2016), BR. 2, STR. 199-218

YAM, S.-C. J.: SURVIVAL GUIDE..
Peirce, C. S. (1931-1958). Collected papers of Charles Sanders Peirce. Edited by C. Hartshorne and P. Weiss (volumes 1-6) and A. Burks (volumes 7 and 8). Cambridge MA: Belknap Press.

Perz, S. G. (2007). Grand theory and context-specificity in the study of forest dynamics: Forest transition theory and other directions. The Professional Geographer, 59(1), 105-114. doi:10.1111/j.1467-9272.2007. 00594.x

Polanyi, M. (1958). Personal knowledge: Towards a post-critical philosophy. Chicago: University of Chicago Press.

Popper, K. [1935] (1959). The logic of scientific discovery. Tubingen: Mohr Siebeck. doi:10.1063/1.3060577

Popper, K. (1963). Conjectures and refutations: The growth of scientific knowledge. London: Routledge

Popper, K. (2008). The two fundamental problems of the theory of knowledge. London \& New York : Routledge.

Savitsky, K., Epley, N., \& Gilovich, T. (2001). Do others judge us as harshly as we think? Overestimating the impact of our failures, shortcomings, and mishaps. Journal of Personality and Social Psychology, 81(1), 44-56. doi:10.1037/0022-3514.81.1.44

Shahar, E., \& Shahar, D. J. (2012). Causal diagrams and three pairs of biases. In N. Lunet (Ed.), Epidemiology-current perspectives on research and practice (pp. 31-62). Rijeka: InTech. doi:10.5772/33486

Shannon, C. E. (1948). A mathematical theory of communication. Bell System Technical Journal, 27(3), 379-423. doi:10.1002/j.1538-7305.1948. tb01338.x

Skinner, Q. [1985] (1990). The return of grand theory in the human sciences. Cambridge: Cambridge University Press. Canto edition.

Somers, M. R. (2005). Beware Trojan horses bearing social capital: How privatization turned solidarity into a bowling team. In G. Steinmetz (Ed.), The politics of method in the human sciences: Positivism and its epistemological others (pp. 233-274). Durham: Duke University Press. doi:10.1215/9780822386889-008

Steinmetz, G. (2005a). Positivism and its others in the social sciences. In G. Steinmetz (Ed.), The politics of method in the human sciences: Positivism and its epistemological others (pp. 1-56). Durham: Duke University Press. doi:10.1215/9780822386889-001

Steinmetz, G. (2005b). Scientific authority and the transition to postFordism: The plausibility of positivism in U.S. sociology since 1945. In G. Steinmetz (Ed.), The politics of method in the human sciences: Positivism and its epistemological others (pp. 275-323). Durham: Duke University Press. doi:10.1215/9780822386889-009

Steinmetz, G. (2005c). The genealogy of a positivist haunting: Comparing prewar and postwar U.S. sociology. Boundary 2, 32(2), 109-135. Swedberg, R. (2012). On Charles S. Peirce's lecture "How to theorize" (1903). Sociologica 2. doi:10.2383/38257.

Swedberg, R. (2016). Before theory comes theorizing or how to make social science more interesting. The British Journal of Sociology, 67(1), 5-22. doi:10.1111/1468-4446.12184 
DRUŠ. ISTRAŽ. ZAGREB GOD. 25 (2016), BR. 2, STR. $199-218$

YAM, S.-C. J.: SURVIVAL GUIDE...
Turner, J. H. (2002). Why are elegant theories under-utilized by sociologists? Contemporary Sociology, 31(6), 664-668. doi:10.2307/3089916

Turner, J. H. (2010a). Theoretical principles of sociology, Volume I: Macrodynamics. New York: Springer.

Turner, J. H. (2010b). Theoretical principles of sociology, Volume II: Microdynamics. New York: Springer.

Turner, J. H. (2012). Theoretical principles of sociology, Volume III: Mesodynamics. New York: Springer. doi:10.1007/978-1-4419-6221-8

Turner, J. H., \& Boyns, D. E. (2001). The return of grand theory. In J. H. Turner (Ed.), Handbook of sociological theory (pp. 353-378). New York: Springer Science+Business Media.

Wallerstein, I. (1996). Open the social sciences: Report of the Gulbenkian Commission on the restructuring of the social sciences. Redwood City: Stanford University Press.

Wittgenstein, L. [1953] (2001). Philosophical investigations. Oxford: Blackwell Publishers.

Zhou, T., Kuscsik, Z., Liu, J.-G., Medo, M., Wakeling, J. R., \& Zhang, Y.-C. (2010). Solving the apparent diversity-accuracy dilemma of recommender systems. Proceedings of the National Academy of Sciences of the United States of America, 107(10), 4511-4515. doi:10.1073/pnas. 1000488107

Yanow, D., \& Schwartz-Shea, P. (2006). Interpretation and method: Empirical research methods and the interpretive turn. Armonk, New York \& London, England: M. E. Sharpe.

\section{Priručnik za preživljavanje velikih teorija i središnja dogma društvenih znanosti}

Shing-Chung Jonathan YAM

Kinesko sveučilište u Hong Kongu, Hong Kong

Velike teorije i empirijsko (kvantitativno ili kvalitativno) istraživanje često se provode odvojeno. U ovom se radu ta odvojenost prati različitim pridržavanjem mjerilâ filozofske, znanstvene i književno-povijesne metode među znanstvenicima. Filozofska metoda oslanja se na dedukciju i razvija u velike teorije dodavanjem pretpostavki koje proizlaze iz životnog iskustva, vodeći konceptualnoj fluidnosti. Nasuprot tomu, znanstvena metoda oslanja se na eksperimente, koji proizvode lakše odredive ishode, kako to tvrdi Popperov (1959) falsifikacionizam. Književno-povijesna metoda dijeli tu predanost determinaciji pružajući dubinsko razumijevanje prostorno-vremenski specifičnih događaja/značenja. Uloge velikih teorija i empirijskog istraživanja preispituju se: velike teorije daju kategorijske sheme, pretpostavke organiziraju u stajališta, otkrivaju skrivene pretpostavke i stvaraju argumente, dok empirijsko istraživanje olakšava kontekstualizirane usporedbe i stvara 
DRUŠ. ISTRAŽ. ZAGREB GOD. 25 (2016), BR. 2, STR. 199-218

YAM, S.-C. J. SURVIVAL GUIDE.. teoriju. Potom se izlaže druga strana priče sa središnjom dogmom društvenih znanosti koja ograničava doseg i određenost svakoga društvenog razumijevanja jednim inverznim odnosom. Središnja dogma ograničava mogućnost društvene spoznaje i uz pomoć institucionalizirane prakse - poput objavljivanja članaka u časopisima ili promaknuća kadrova - koči akademski razvoj. Konačno, u radu se tvrdi da velike teorije moraju, kako bi "preživjele", identificirati i ponovno prigrliti vlastito mjerilo, što bi potom moglo dovesti do samopouzdane komunikacije s rezultatima dobivenim drugim metodama.

Ključne riječi: filozofija društvenih znanosti, epistemologija, sociologija znanja, doseg, određenost 